\title{
Do sustainable institutional investors contribute to firms' environmental performance? Empirical evidence from Europe
}

\author{
Othar Kordsachia ${ }^{1}$ (D) Maximilian Focke ${ }^{2} \cdot$ Patrick Velte $^{2}$
}

Received: 17 June 2020 / Accepted: 15 July 2021 / Published online: 26 July 2021

(c) The Author(s) 2021

\begin{abstract}
In light of current climate change discussions, this paper analyzes the effect of ownership structure on a firm's environmental performance with a subsequent focus on corporate emission reduction. Based on a cross-national European sample consisting of 7384 firm-year observations between 2008 and 2017, this study explores the relationship between sustainable institutional investors and environmental performance. In line with prior research and embedded in an agency theoretical framework, the nature of institutional investors may act as a stimulating driver towards green business practices. Sustainable institutional investors are defined based on their signatory status to the UN Principles for Responsible Investment and their (long-term) investment horizons. The first classification stems from a content-driven sustainability perspective, while the second is derived from temporal sustainability. The results indicate that sustainable institutional ownership is positively associated with a firm's environmental performance. Further investigations reveal that sustainable institutional investor ownership is also positively associated with firms' willingness to respond to the Carbon Disclosure Project. These results indicate a higher carbonrisk awareness in firms with greater sustainable institutional investor ownership. Our paper significantly contributes to prior empirical research on institutional ownership and environmental performance and offers useful theoretical and practical implications. It focusses on a still-underdeveloped research area, namely organizations and their relationships with the natural environment, including institutional equity ownership as a driver towards greener practices on a corporate level.
\end{abstract}

Keywords Sustainable investors · Institutional investors · Investment horizon · Corporate social responsibility $\cdot$ Environmental performance

Othar Kordsachia

othar.kordsachia@uni-hamburg.de

1 Department of Socioeconomics, University of Hamburg, Rentzelstraße 7, 20146 Hamburg, Germany

2 Institute of Management, Accounting \& Finance, Leuphana University Lüneburg, Universitätsallee 1, 21335 Lüneburg, Germany 
JEL Classification G30 - M14

\section{Introduction}

There is a growing trend towards incorporating sustainability issues in investment decisions by institutional investors (Revelli and Viviani 2015; Reverte 2016; Palacios-González and Chamorro-Mera 2018; Utz 2019). Extant studies find evidence for a positive relationship between institutional ownership and invested firms' environmental, social and governance (ESG) performance (Faller and Knyphausen-Aufseß 2018). In light of the ongoing discussion about the value relevance of firms' sustainability engagements, this indicates that institutional investors do not regard these engagements as an agency problem (Barnea and Rubin 2010; Dam and Scholtens 2012; Lourenço et al. 2012).

However, although institutional investors' objectives and investment agendas vary, previous studies have predominantly regarded them as a homogenous group with common characteristics (Ryan and Schneider 2003; Faller and KnyphausenAufseß, 2018). In that regard, it is crucial to differentiate between specific investor types and characteristics (Rees and Mackenzie 2011; Escrig-Olmedo et al. 2017). In addition, extant studies mostly take an aggregated perspective on firms' ESG performance (Escrig-Olmedo et al. 2014; Faller and Knyphausen-Aufseß, 2018). We argue that, given the great importance of reducing corporate externalities for a wide range of corporate stakeholders, a more fine-grained analysis is warranted. We therefore take a more differentiated perspective on the interplay between institutional investors and corporate environmental performance, especially carbon performance. Furthermore, most studies focus on US firms exclusively, although the pressure on institutional investors regarding the integration of sustainability issues into their decision-making processes varies around the world. One source of this variation is a result of differences in the sustainability preferences of the investors' client base (Gibson et al. 2020). In particular, environmental norms are relatively stronger in Europe, and sustainable investing is more broadly practiced (Liang and Renneboog 2017; Dyck et al. 2019). Another important source of variation results from different regulatory requirements: there is still an open debate about whether fiduciary duties should include the consideration of environmental factors in the United States. However, the EU established a sustainable finance framework to make the integration of these factors an integral part of institutional investing (EU 2017/828; Gibson et al. 2020) Thus, the EU has unique framework conditions, which have hardly been considered within research so far (Escrig-Olmedo et al. 2014; Faller and KnyphausenAufseß, 2018).

Based on an agency theoretical framework, the purpose of this paper is to take a disaggregated perspective on sustainable institutional investors and different aspects of European firms' environmental performance. We identify two types of sustainable institutional investors-content-driven, socially responsible investors and timedriven, long-term investors. Classical principal agent theory assumes that institutional investors are a homogeneous shareholder group with a clear focus on financial performance (shareholder value policy). Institutional investors represent a key 
monitoring instrument as part of external corporate governance. According to classical agency theory, investors may neglect environmental issues and put pressure on management to foster short-term financial performance, e.g., to increase dividends. Our study makes useful key theoretical and practical contributions as institutional investors' preferences and influences are not only related to financial performance but to environmental performance. Sustainable institutional investors as a relevant shareholder group in international capital markets play a key role in strengthening the environmental activities of European listed corporations. Therefore, managers and regulatory bodies should be aware of this new kind of non-financial shareholder activism, e.g., with regard to say on pay voting and other monitoring activities of institutional investors. Our results imply that management behaviour is affected by the nature and preferences of the investor base. Our analysis further indicates that investor collaboration via collective principles and frameworks like the UN Principles for Responsible Investment (UN PRI) is relevant in this context.

\section{Agency theory}

Principal agent theory represents the central theorem within prior institutional ownership research (Bebchuk et al. 2017; Faller and Knyphausen-Aufseß 2018). Based on the separation of ownership and control, Jensen and Meckling (1976) characterize the overarching problem that managers as agents may have dampened incentives to maximize corporate efficiency. A principal-agent relationship arises through the delegation of decision-making authority from institutional investors as principals to managers as agents (Jensen and Meckling 1976). Agency conflicts are related to information asymmetries and conflict of interests between principals and agents, resulting in moral hazards and self-serving actions. To decrease those agency conflicts, there is a need to implement monitoring and incentive-alignment mechanisms within the firm, e.g., useful management compensation systems. According to principal agent theory, institutional investors represent a key monitoring tool as part of external corporate governance. They should decrease the moral hazard of top managers by strong monitoring duties, e.g., based on their exit and voice options. Traditional agency theory focusses on the financial value maximization of listed firms and neglects ESG performance. Because ESG-related investments may reduce shortterm financial performance, shareholders may put pressure on the management to disregard ESG performance and instead strengthen current financial performance measures and increase dividends. Classical agency theory assumes that shareholders' preferences are homogeneous and mainly rely on financial preferences (Jensen and Meckling 1976).

More recently, we recognize several attempts in the literature at an 'enlightened' shareholder value approach with an integration of other stakeholder needs (Velte 2020). According to the business case argument for ESG (Schaltegger et al. 2019), successful ESG strategies should lead to better financial performance and increased firm value in the long run. Various prior meta-analyses state a positive link between ESG performance and financial performance (e.g., Busch and Friede 2018). As institutional investors are focussed on maximizing firm value, they may also include 
ESG aspects in their decision-making, e.g., appropriate ESG performance and transparent ESG disclosures. Modern interpretations of agency theory, e.g., stakeholder agency theory (Hill and Jones 1992), remove the strict assumptions of homogeneous preferences of institutional investors and differentiate between types and natures. Thus, institutional investors might pursue ESG strategies due to their potential to positively influence companies' financial performance (Dam and Scholtens 2012). In view of the current discussion on climate change policies and the various regulations on carbon finance, environmental issues are likely to have a key impact on business models and future firm valuation. As investment decisions by institutional investors should be made on the basis of risk and return (Cumming and Johan 2007; Hoq et al. 2010), shares of companies that prevalently engage in environmental issues are supposedly less risky investments (Graves and Waddock 1994; Mahoney and Roberts 2007). Thus, institutional investors will consider environmental expenses as useful investments if they reduce investment risk (Mahoney and Roberts 2007). As this strategy will be mainly determined by the individual preferences of certain groups of institutional investors, we recognize the increased power of sustainable institutional investors who are interested in investments in sustainable firms (Dyck et al. 2019). Their sustainability-related preferences may be both long term and content driven, as we will explain in the next chapter. In particular, firms' exposure to carbon risks with emphasis on European carbon-intensive industries has become a dominant topic in business and is also currently discussed in theoretical contributions to agency theory (Hoffmann and Busch 2008; Velte et al. 2020). Carbon risks are likely to substantially impact the future financial valuation of firms. Thus, institutional investors expect successful environmental (carbon) management systems, which will increase environment (carbon) performance and also long-term financial performance.

\section{Literature review and hypothesis development}

\subsection{Content-driven, socially responsible investors and corporate environmental performance}

A growing body of academic literature investigates the influence of institutional investors as a key corporate governance mechanism that affects invested firms' nonfinancial performance (Dam and Scholtens 2012; Dyck et al. 2019; Gloßner 2019; Kim et al. 2019a; Xiang et al. 2020). This specific investigation of institutional investors is a result of their greater influence on corporate decision-making in recent years (Shleifer and Vishny 1997; Aghion et al. 2013; Sikavica et al. 2018; Kordsachia 2020). Today, shares of the largest corporations around the world are owned by institutions rather than individuals (Dyck et al. 2019). While early research on institutional investors commonly considers them a homogenous group with similar objectives and investment agendas (Gillan and Starks 2000), other studies argue that each institutional investor has unique characteristics (Kim et al. 2019a). One important distinction refers to their investment horizons. In recent studies, Gloßner (2019), Kim et al. (2019a) and Oikonomou et al. (2020) distinguish between the impacts 
of short- and long-term investors on firms' ESG performance because different investment horizons may affect the incentive to monitor and, in turn, affect various corporate decisions and practices (Bushee 1998; Chen et al. 2007; Gaspar et al. 2013). Another separation pertains to content-driven, socially responsible investing (Majoch et al. 2017; Alda 2019). We only recognize a few studies on this topic (Dyck et al. 2019; Kim et al. 2019b; Alda 2019). Dyck et al. (2019) find that socially responsible investors, based on an international sample, have a greater impact on the invested firms' environmental and social performance than traditional institutional investors. Kim et al. (2019b) refer to the US capital market and state that local, socially responsible investment funds reduce the total quantity of toxic chemicals, assuming a positive impact on environmental performance. Moreover, based on a UK setting (Alda 2019), socially responsible pension funds increase environmental performance. We note that a combination of long-term investors, socially responsible investors and different dimensions of firms' environmental performance is absent from the present literature. Moreover, hardly anything is known about European companies in this context (Faller and Knyphausen-Aufseß, 2018).

Environmental investments are often described as a special form of strategic investment by a firm (Jia and Zhang 2013), and key shareholders are typically assumed to be involved in such decisions (Oh et al. 2011). The issue of climate change in particular has attracted growing interest in business practice due to its numerous impacts on ecosystems and, subsequently, on human lives (Jung et al. 2018). Due to their substantial voting power and ability to acquire relevant information from firms' management, institutional investors can engage in active oversight and require improved environmental performance. Due to negative stakeholder reactions or stakeholder pressure on climate change policies, managers have an incentive to align their positions in a firm against the interests of the shareholders by engaging in stakeholder-related activities (Cespa and Cestone 2007; Pagano and Volpin 2005; Kock et al. 2012). In this case, institutional investors may influence management behaviour towards greener practices because they are often more attentive to a firm's strategic decisions than other, smaller shareholders (Calza et al. 2016). In this context, socially responsible investors are expected to hold a homogeneous set of ethical values. They intrinsically engage in active oversight of corporate environmental engagement (Majoch et al. 2017).

In addition to ethical values, other factors support the active engagement of socially responsible investors to improve environmental performance. Better environmental standards and policies in an industrial firm can significantly reduce the risk of costly environmental incidents in the long run (Feldman et al. 1997; Sharfman and Fernando 2008). Chava (2014) points out that firms with fewer environmental issues have lower cost of capital. Li et al. (2020) report that high-polluting stocks significantly underperform low-polluting stocks. Given the prominence of environmental issues in the media, e.g., VW's software scandal, and the increasing concern among retail investors for environmental protection, we assume that socially responsible investors engage in environmental monitoring to serve their client bases. For example, reducing $\mathrm{CO}_{2}$ emissions is a major concern of sustainable investors around the world in terms of firm reputation and disruptive business models (Ioannou and Serafeim 2015). These investors possess multi-attribute value 
functions regarding financial versus non-financial performance and may even forego financial gains for 'ethical dividends' (Ainsworth et al. 2018). Monitoring efforts to increase environmental activities may be beneficial for socially responsible investors to the extent that it secures additional investment inflow from its ethically motivated client base.

Based on prior research (e.g., Dyck et al. 2019; Kim et al. 2019b; Alda 2019) and the aforementioned agency theoretical arguments, socially responsible investors are expected to promote environmental performance through their investment decisions, active engagement and monitoring. The growing recognition of the materiality of environmental performance and its progressive mainstreaming, reflected in the demand for socially responsible investors, are a source of salience for such investors (Riedl and Smeets 2017). Given the multi-dimensionality of firms' environmental engagements across a wide range of material environmental issues, we expect that the positive association between socially responsible investors' ownership and firms' environmental performance is robust in the analysis of sub-categories. We therefore posit the following hypotheses:

H1a Ownership of socially responsible investors is positively associated with corporate environmental performance.

H1b Ownership of socially responsible investors is positively associated with all environmental category scores.

\subsection{Time-driven, long-term investors and corporate environmental performance}

In addition to socially responsible investors, long-term investors, as a second type of sustainable institutional investor, may also benefit from the improvement of a firm's environmental performance. This benefit seems to be dependent on the institutional investors' investment horizons (Kim et al. 2019a). The proportion of long-term investors determines whether firms are able to make more long-term investments (such as environmentally related investments). Short-term investors do not care much about environmental performance and do not pursue the objective of longterm firm value maximization (Erhemjamts and Huang 2019). Environmental investments may lead to higher firm performance in the long run since environmentally irresponsible firms may be subject to punishment from stakeholders and government sanctions (Oh et al. 2011; Calza et al. 2016). In contrast to the low number of studies on content-driven, socially responsible investors, we recognize an increased amount of research on time-driven, long-term investors and their overall impact on environmental and social performance (e.g., Meng and Wang 2020; Erhemjamts and Huang 2019; Fu et al. 2019; Gloßner 2019). Prior studies find that long-term investors, especially institutional investors, strengthen environmental and social performance based on US settings (Meng and Wang 2020; Erhemjamts and Huang 2019; Fu et al. 2019; Gloßner 2019; Kim et al. 2019a; Lamb and Butler 2018; Boubaker et al. 2017; Neubaum and Zahra 2006). 
In contrast to this, myopic investment behaviour refers to underinvestment in long-term, intangible projects like research and development for the purpose of meeting short-term goals (Bushee 1998, 2001). In that case, a firm could skimp on pollution control to increase short-term profits, exposing the firm to liabilities, such as environmental clean-up costs (Calza et al. 2016). Barrot (2012) finds that the number of a firm's patents increases with private equity funds that have longer investment horizons. Long-term institutional investors have an incentive to persuade and monitor managers towards agendas that enhance long-run value maximization (Gaspar et al. 2005). It seems that besides altruistic motives, investment horizon determines the financial advantageousness of environmental investments (Calza et al. 2016). Based on prior research (e.g., Meng and Wang 2020; Erhemjamts and Huang 2019; Fu et al. 2019) and the aforementioned agency theoretical arguments, it is not only socially responsible investors who have an incentive to promote environmental performance. Institutional investors with long-term investment horizons will also use those strategies. We therefore posit the following hypotheses:

H2a Institutional investors with long-term investment horizons are positively associated with corporate environmental performance.

H2b Institutional investors with long-term investment horizons are positively associated with all environmental category scores.

\subsection{Sustainable institutional investors and carbon awareness}

Based on the rationales we have presented regarding the influence of sustainable institutional investors on environmental performance, we further consider an aspect that is directly linked to this line of argumentation. To evaluate a company's greenhouse gas (GHG) emissions in a differentiated manner, investors need a sufficient source of information. The Carbon Disclosure Project (CDP) is a non-profit organization that annually analyzes companies' GHG emissions by sending out questionnaires. Previous studies identify that the likelihood of answering the questionnaires and related carbon disclosure scores increase with the share of domestic institutional investors (Wegener et al. 2013) and the ratio of institutional investors (Akbaş and Canikli 2019; Jaggi et al. 2018). Furthermore, Kim and Lyon (2011) demonstrate that institutional investors' consciousness about climate change may increase the awareness of management and shareholder value. Alda (2019) represents the only study that concentrates on the impact of socially responsible pension funds on carbon performance, finding a positive impact. The impact of long-term institutional investors on carbon performance and disclosure has not been included as a research topic yet. In view of the limited validity of carbon emission proxies (e.g., Velte et al. 2020), we refer to the assumptions by Jung et al. (2018). The authors consider carbon disclosure via CDP participation as a relevant proxy for carbon awareness. Sustainable institutional investors are assumed to incorporate climate risks into their investment decisions and therefore encourage better carbon disclosure, which ultimately increases carbon awareness (Kolk et al. 2008; Jiang and Habib 2009; Velte 
et al. 2020). Based on prior research (e.g., Alda 2019) and the aforementioned agency theoretical arguments, we additionally posit the following hypothesis:

H3 Sustainable institutional investor ownership is positively associated with carbon awareness.

\section{Methodology}

\subsection{Sample selection}

Our sample is constructed from a range of data sources. Sample selection began with firms that are headquartered in European countries and included in the ASSET4 database from 2008 to 2017. ASSET4 acquires information from annual reports, ESG reports, non-governmental organisations and news sources for large, publicly traded companies annually. We hand-collected the UN PRI signatory statuses of investors directly from the UN PRI signatory and outreach. The authors researched the firm structure of each signatory and included subsidiaries as signatories if they also communicated their engagement with the UN PRI on the company website. This approach mitigates concerns over the applicability of UN PRI to lower-level units of parent companies. We retrieved detailed information about each company's 100 largest shareholders with a unique InvestorPermid from the Thomson Reuters Eikon database, which collects ownership information from a variety of sources, such as SEC 13F filings, annual reports, mutual fund aggregates, IPO prospectuses and the UK Share Register. We manually matched the UN PRI signatory status with over 800,000 firm-year shareholdings based on the names of the individual shareholders. For each firm-year observation, we calculated the percentage of total shares outstanding owned by UN PRI signatories and match this aggregated variable with the ASSET4 database using unique Reuters instrument codes. We deleted 11 observations with UN PRI ownership over 100\%. Upon inspection, we determined that these data errors are likely due to temporal overlaps of investor information from the various aggregated data sources. Finally, we obtained Worldscope financial statements and stock market valuation data and retained 7384 firm-year observations from 921 firms with available data for hypothesis testing.

\subsection{Socially responsible investors}

Following Gibson et al. (2020), Dyck et al. (2019) and Gloßner (2019), we define socially responsible investors as institutional investors that are signatories to the UN PRI and pledge to closely monitor the sustainability practices of the invested firms. These investors are expected to possess a homogeneous set of ethical values according to which they engage in active oversight of corporate environmental engagement (Clark and Crawford 2012; Gond and Piani 2013; Oh et al. 2013; Majoch et al. 2017; Laurel-Fois 2018). As invested financial stakeholders, their incentive is to monitor 
managerial behaviour in alignment with a multi-attribute value function regarding firms' financial and environmental performance.

By following the voluntary principles for investment and decision-making, these investors are obliged to outline the incorporation of sustainability issues in investment analysis in publicly available annual transparency reports. To strengthen stakeholder trust in the implementation of the principles, the UN PRI imposes three minimum requirements for potential and existing signatories. First, the responsible investment policy of signatories has to cover at least $50 \%$ of the firm's assets under management. Second, they need to declare internal or external staff charged with implementing the responsible investment policy. Third, there must be senior-level oversight and accountability regarding responsible investment objectives and policies. These key requirements ensure that the population of signatories is connected via homogeneous implementation mechanisms, thus reducing the variability and effectiveness of responsible investment approaches. Given the voluntary nature of the principles, UN PRI signatories can be assumed to have similar ethical beliefs regarding corporate sustainability to a certain degree. These beliefs are probably reflective of their environmentally conscientious retail investor bases. The UN PRI also advocates the business case for ESG by articulating that the inclusion of ESG issues in portfolio construction yields superior long-term value over traditional approaches based only on financial information. Long-termism regarding investment horizons is another concept stressed by the UN PRI: while it does not put forth specific requirements regarding signatories' investment turnover, it does broadly advocate active, long-term ownership. To operationalize the sustainability preferences of institutional ownership, we measure the influence of UN PRI signatories in firms' ownership structures. Specifically, we calculate the total equity owned by UN PRI signatories with respect to each firm-year observation in our sample (PRI_PERCENT). This calculation is based on year-end shareholdings of the largest 100 investors in each firm. PRI_PERCENT is our variable to capture the influence of socially responsible investors in a firm's ownership structure on environmental performance through monitoring efforts.

\subsection{Institutional investors with long-term investment horizons}

Next to socially responsible investors, we construct a direct measure for the determination of long-term institutional investors. This measure considers investors' investment characteristics on the single security level of analysis. In particular, we utilize the date of the initial investment of each investor $j$ in company $i$ to capture the invested time period. For each investor-year observation, we calculate the number of years for which an investor continuously holds shares in a company. In a subsequent step, to create the firm-year level measure INV_HORIZON, we calculate the equityweighted average of years since the initial investment in company $i$ by investor $j$ in year $t$. A larger number indicates an ownership structure in which most equity is owned by long-established institutional investors. These investors are likely very familiar with the fundamentals of the invested firm and likely to have established strong relationships with the firm's management. Compared to the portfolio turnover 
approach to classify long-term investors in US companies (e.g., Gaspar et al. 2005), our approach captures the familiarity of single investors with the invested company. This strategy might have a substantial influence on investors' ability to actively monitor companies' management.

\subsection{Environmental performance}

There has been a long-standing debate about the link between ESG performance and financial performance. Traditional principal-agent theory as it relates to ESG performance argues that ESG investments come at the expense of value-added projects and therefore destroy shareholder value (Jensen and Meckling 1976). Since then, proving or disproving the legitimacy of such investments has remained a controversial subject of academic discussion. To settle this debate, numerous studies have analyzed the relationship between ESG performance and financial performance (Carroll and Shabana 2010). Although prior empirical results have not been unambiguous, Faller and Knyphausen-Aufseß (2018), van Gils et al. (2014) and Margolis et al. (2009) undertake meta-analyses of this relationship, indicating that ESG performance at the very least does not impair financial performance in the long run (Dam and Scholtens 2012; Lourenço et al. 2012). One potential explanation for ambiguous and partially contradictory empirical findings is the multi-dimensionality and complexity of ESG performance. Companies may treat environmental and social issues differently in practice (Erhemjamts and Huang 2019). Aggregating all dimensions of ESG fails to account for cases in which firms are only responsible in some dimensions, such as the environment (Walls et al. 2012). The findings of Faller and KnyphausenAufseß (2018) indicate the need to use more fine-grained approaches to clarify the relationship between institutional ownership and ESG performance. In light of the current issue of climate change, this study focusses on the environmental component of ESG performance. To further increase the level of detail, we consider emission reduction, product innovation and resource use as sublayers of environmental performance. The perceived value of potential benefits within these dimensions may vary between different types of shareholders as they possess individual value functions with respect to short-term financial or long-term environmental benefits (Rees and Mackenzie 2011).

We obtained data on firms' environmental performance from the Thomson Reuters ASSET4 ESG database. The ESG score consists of 178 specific line items assigned to the ESG pillar scores. We use the Environmental pillar score (E_PILLAR) as a measure of a company's overall environmental performance. This proprietary weighted aggregate pillar score (ASSET4 z-score) captures a firm's environmental performance in relation to the performance of all other firms in the same industry. E_PILLAR also incorporates three category scores relating to emission reduction, product innovation and resource use with 19, 22 and 20 assigned line items, respectively. Because ASSET4 provides aggregate z-scores along these categories, we supplement our analysis by these more fine-grained measures for firms' environmental performance. The variables EMS, INNO and RES represent each 

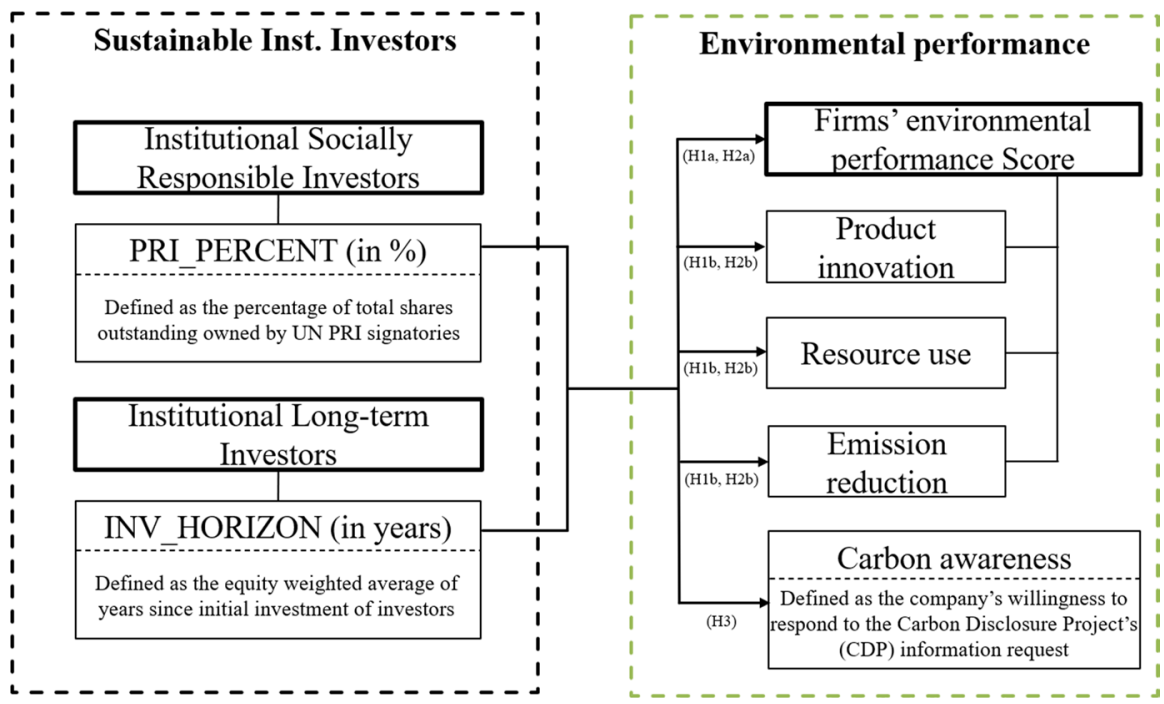

Fig. 1 Research framework and main variables

firm's performance in the categories of emission reduction, product innovation and resource use, respectively.

Finally, we follow the approach by Jung et al. (2018) and proxy carbon-risk awareness with the company's willingness to respond to the CDP's information request. The CDP survey collects data on corporate environmental performance on an annual basis. Since its launch in 2000, over 8400 companies have reported through CDP on climate change and other pressing environmental issues. For each company invited to respond to the survey, the CDP publicly publishes the status of the information request. The variable $\mathrm{CA}$ is one if the company responds to the request and zero otherwise. We matched our dataset with the CDP data by scraping the CDP website for all company names and their derivatives (alternate spellings and abbreviations). This procedure left us with 5,575 firm-year observations with available data for regression analysis. At $73 \%$, the response rate to the survey was relatively high within our sample.

Figure 1 portrays our research framework and the main variables of our study.

\subsection{Control variables}

We control for a range of firm characteristics that extant literature shows to be associated with corporate environmental performance. We include firm size (SIZE) because larger firms are likely to be subject to greater external pressure to engage in environmentally friendly activities (Kim et al. 2019a). SIZE is defined as the natural logarithm of total assets. Next, we control for different variables related to a firm's financial performance, which may predict the firm's ability to allocate resources to environmental engagements. Following the slack-resource theory (Waddock and Graves 1997), more profitable firms have more organizational slack, which may 
enable them to make greater commitments to environmental activities. As in related studies (e.g., Dyck et al 2019; Kim et al. 2019a; Nofsinger et al. 2019; Oh et al. 2011; Oikonomou et al. 2020; Zolotoy et al. 2019), we include the firm's debt ratio (DEBT_RATIO), asset tangibility (TANGIBILITY), Tobin's q (Q), return of assets (ROA) and stock price volatility (VOLA). We also include external corporate governance mechanisms in the context of ESG performance (Harjoto and Jo 2011; Pekovic and Vogt 2020): the extent of analyst following (ANALYST), the percentage of shares held by public investors (FREE_FLOAT) and dummy variables for the Dow Jones Sustainability Index listing in the European sub-section (DJSI_EU). Finally, as internal governance measures, we control for board gender diversity (BGD) and board size (BS). Extant studies find a positive association between female board representation and ESG performance (e.g., Galbreath 2018; Lopatta et al. 2020), possibly owing to an increased sensitivity to sustainability issues (Williams 2003). Likewise, larger boards could be more likely to engage in ESG activities due to increased knowledge (Cabeza-García et al. 2018). None of the explanatory variables are line items included in the calculation of the environmental pillar score or its sub-categories. Variable definitions for all variables are presented in Table 1.

\subsection{Model design}

We conducted regression analysis for hypothesis testing. To examine the relation between (lagged) ownership characteristics and firms' overall environmental performance and to test hypotheses 1 and 2, we apply the following specification (Eq. 1):

$$
\begin{aligned}
E_{-} \text {PILLAR }_{i, t+1}= & \beta_{0}+\beta_{1} \text { OwnershipCharacteristic }_{i, t}+\gamma \boldsymbol{X}_{i, t} \\
& +\sum \text { COUNTRY }_{i}+\sum \operatorname{INDUSTRY}_{i}+\sum \text { YEAR }_{t}+\varepsilon_{i, t+1}
\end{aligned}
$$

Here $\boldsymbol{\gamma} \boldsymbol{X}_{i, t}$ is a vector for control variables defined in the previous section, $\sum$ COUNTRY $_{i}$ denotes country fixed effects, $\sum$ INDUSTRY $Y_{i}$ denotes industry fixed effects based on two-digit SIC codes, $\sum Y E A R_{t}$ denotes year fixed effects and $\varepsilon_{i, t+1}$ is the regression error term. Environmental performance is forwarded by one year in order to model a possible causal relationship and to mitigate potential endogeneity effects due to reverse causality. Institutional ownership variables refer to either socially responsible investors (measured by the variable PRI_PERCENT) or long-term institutional investors (measured by the variable INV_HORIZON). We estimate Eq. 1 using fixed effects regression with robust standard errors adjusted for heteroscedasticity (Huber-White sandwich estimator of variance). ${ }^{1}$ For a more disaggregated analysis and to test hypotheses $1 \mathrm{~b}$ and $2 \mathrm{~b}$, we also use the three

\footnotetext{
1 Since over $80 \%$ of variance is due to differences across panels (intraclass correlation $>0.8$ ), we do not report results based solely on within-firm variance. This is consistent with earlier research showing that firms' environmental performance ratings are relatively time-invariant. Similarly, firms' ownership structures only change incrementally over the sample period. The results are robust using firm, industry or country-clustered standard errors.
} 


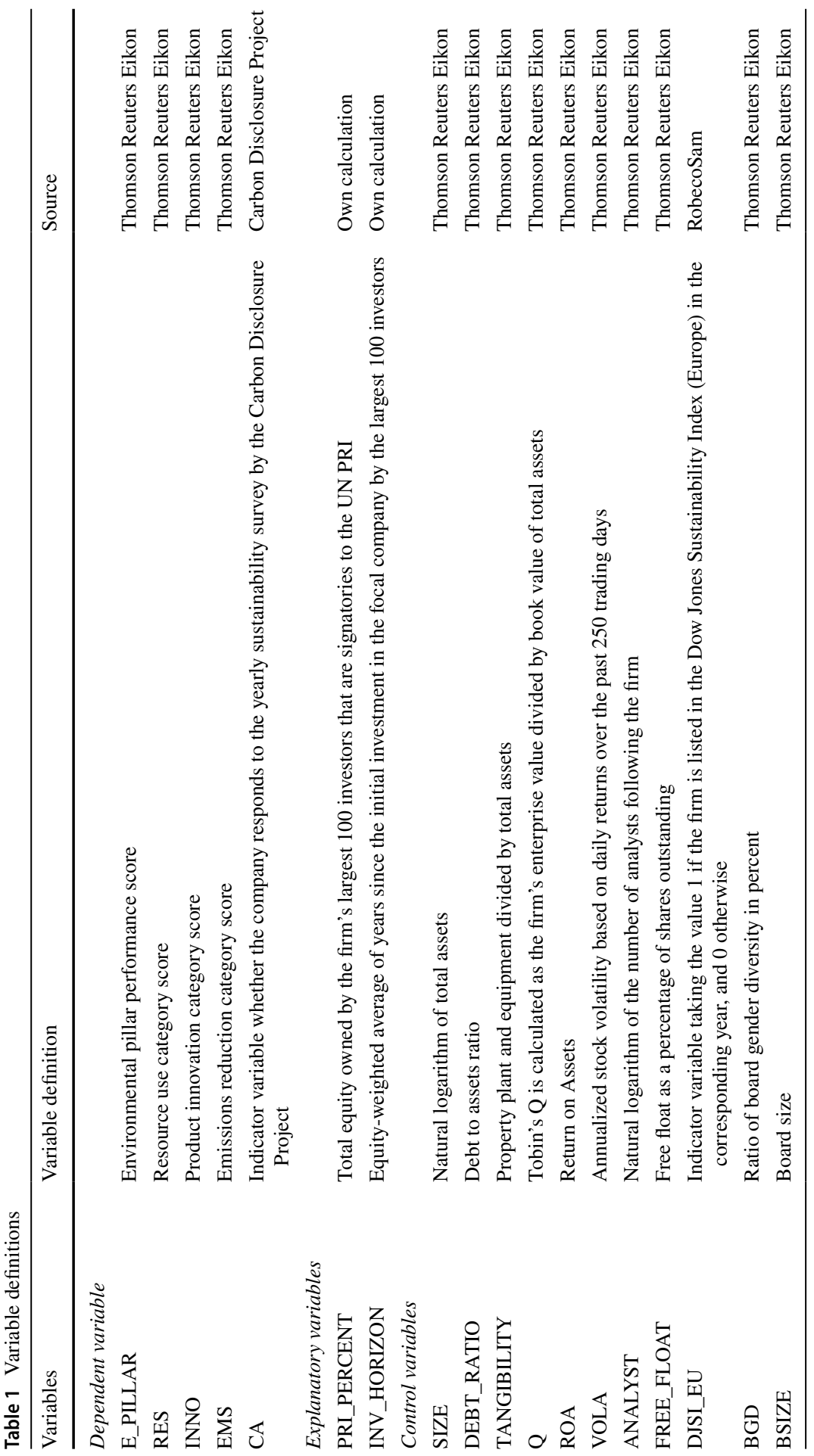


environmental category scores (EMS, INNO, RES) as alternative dependent variables (Eqs. 2, 3 and 4):

$$
\begin{aligned}
\text { EMS }_{i, t+1}= & \beta_{0}+\beta_{1} \text { OwnershipCharacteristic }_{i, t}+\gamma \boldsymbol{X}_{i, t}+\sum \text { COUNTRY }_{i} \\
& +\sum \text { INDUSTRY }_{i}+\sum \text { YEAR }_{t}+\varepsilon_{i, t+1} \\
\text { INNO }_{i, t+1}= & \beta_{0}+\beta_{1} \text { OwnershipCharacteristic }_{i, t}+\gamma \boldsymbol{X}_{i, t}+\sum \text { COUNTRY }_{i} \\
& +\sum \text { INDUSTRY }_{i}+\sum \text { YEAR }_{t}+\varepsilon_{i, t+1} \\
\text { RES }_{i, t+1}= & \beta_{0}+\beta_{1} \text { OwnershipCharacteristic }_{i, t}+\gamma \boldsymbol{X}_{i, t}+\sum \text { COUNTRY }_{i} \\
& +\sum \text { INDUSTRY }_{i}+\sum \text { YEAR }_{t}+\varepsilon_{i, t+1}
\end{aligned}
$$

Finally, to examine the link between sustainable institutional investors and carbon awareness and to test hypothesis 3, we include our proxy for carbon awareness (CA) as the dependent variable and run the following logistic regression (Eq. 5):

$$
\begin{aligned}
\text { CA }_{i, t+1} & =\beta_{0}+\beta_{1} \text { OwnershipCharacteristic }_{i, t}+\gamma \boldsymbol{X}_{i, t}+\sum \text { COUNTRY }_{i} \\
& +\sum \text { INDUSTRY }_{i}+\sum \text { YEAR }_{t}+\varepsilon_{i, t+1}
\end{aligned}
$$

\section{Empirical findings}

\subsection{Descriptive statistics and correlation analysis}

Panel A of Table 2 presents the sample distribution across the countries of the firms' headquarters. Panel B of Table 2 reports the descriptive statistics of the key variables used for hypothesis testing. On average, UN PRI signatories own $17.93 \%$ of equity outstanding with a median value of $12.19 \%$. The equity-weighted average holding period since the initial investment of each firm's largest 100 shareholders is 8.25 years. The average environmental (social) pillar score is 49.85 (53.93). Average values of the environmental category scores are similarly around 54 and $73 \%$ of firms responding to the survey of the CDP. The correlation analysis is presented in Table 3. The correlation coefficients do not raise concerns regarding multicollinearity affecting our analysis. The variance inflation factor is lower than 10 with respect to all independent variables used for hypothesis testing.

\subsection{Regression results}

Table 4 presents our results on the association between our two sustainable institutional investor proxies and firms' overall environmental performance as measured 
Table 2 Sample composition and summary statistics

\begin{tabular}{|c|c|c|c|c|c|c|c|c|}
\hline \multirow{2}{*}{\multicolumn{2}{|c|}{ Country of headquarters }} & \multirow[t]{2}{*}{$\mathrm{N}$} & \multicolumn{6}{|c|}{ Mean of } \\
\hline & & & \multicolumn{2}{|c|}{ E_PILLAR } & \multicolumn{2}{|c|}{ PRI_PERCENT } & \multicolumn{2}{|c|}{ INV_HORIZON } \\
\hline \multicolumn{9}{|c|}{ Panel A: Sample composition by county of headquarters } \\
\hline \multicolumn{2}{|l|}{ Austria } & 170 & \multicolumn{2}{|l|}{47.87} & \multicolumn{2}{|l|}{7.02} & \multicolumn{2}{|l|}{7.15} \\
\hline \multicolumn{2}{|l|}{ Belgium } & 269 & \multicolumn{2}{|l|}{42.94} & \multicolumn{2}{|l|}{8.73} & \multicolumn{2}{|l|}{8.54} \\
\hline \multicolumn{2}{|l|}{ Cyprus } & 10 & \multicolumn{2}{|l|}{61.13} & \multicolumn{2}{|l|}{15.57} & \multicolumn{2}{|l|}{6.32} \\
\hline \multicolumn{2}{|l|}{ Czech Republic } & 40 & \multicolumn{2}{|l|}{28.82} & \multicolumn{2}{|l|}{12.18} & \multicolumn{2}{|l|}{6.06} \\
\hline \multicolumn{2}{|l|}{ Denmark } & 240 & 43.8 & & 8.94 & & 8.23 & \\
\hline Finland & & 270 & 60.67 & & 12.73 & & 8.34 & \\
\hline France & & 960 & 63.8 & & 11.07 & & 9 & \\
\hline Germany & & 889 & 53.72 & & 12.67 & & 7.85 & \\
\hline Gibraltar & & 10 & 30.63 & & 10.23 & & 5.56 & \\
\hline Greece & & 190 & 37.46 & & 4.3 & & 6.55 & \\
\hline Guernsey & & 79 & 13.17 & & 28.02 & & 4.35 & \\
\hline Hungary & & 40 & 55.56 & & 11.64 & & 7.97 & \\
\hline Ireland; Republic of & & 310 & 38.61 & & 19.65 & & 8.02 & \\
\hline Isle of Man & & 20 & 13.93 & & 7.75 & & 3.51 & \\
\hline Italy & & 449 & 46.92 & & 6.65 & & 7.9 & \\
\hline Jersey & & 40 & 27.88 & & 18.48 & & 4.54 & \\
\hline Luxembourg & & 79 & 41.78 & & 6.7 & & 6.98 & \\
\hline Malta & & 20 & 11.65 & & 23.05 & & 5.04 & \\
\hline Netherlands & & 330 & 52.91 & & 12.46 & & 7.23 & \\
\hline Norway & & 190 & 50.87 & & 9.88 & & 8.39 & \\
\hline Poland & & 249 & 26.49 & & 7.54 & & 6.31 & \\
\hline Portugal & & 100 & 62.89 & & 6.41 & & 7.96 & \\
\hline Romania & & 10 & 2.02 & & 0.98 & & 6.6 & \\
\hline Russia & & 308 & 29.8 & & 1.65 & & 4.22 & \\
\hline Spain & & 410 & 63.01 & & 6.36 & & 8.05 & \\
\hline Sweden & & 670 & 53.91 & & 16.55 & & 8.96 & \\
\hline Switzerland & & 709 & 42.85 & & 11.41 & & 8.04 & \\
\hline Ukraine & & 10 & 8.14 & & 7.03 & & 3.32 & \\
\hline United Kingdom & & 2926 & 43.93 & & 33.32 & & 9.15 & \\
\hline Variables & $\mathrm{N}$ & Mean & $\mathrm{SD}$ & Qual & & & & \\
\hline & & & & Min & 0.25 & Median & 0.75 & $\operatorname{Max}$ \\
\hline Panel B: Summary s & tatistic: & & & & & & & \\
\hline E PILLAR & 7384 & 49.85 & 27.53 & 0 & 27.71 & 51.51 & 74.2 & 98.72 \\
\hline RES & 7374 & 53.96 & 24.43 & 0 & 34.94 & 55.17 & 74.07 & 98.69 \\
\hline INNO & 7290 & 54.09 & 24.4 & 0 & 35.06 & 55.35 & 74.21 & 98.69 \\
\hline EMS & 7384 & 53.93 & 24.44 & 0 & 34.9 & 55.15 & 74.05 & 98.69 \\
\hline $\mathrm{CA}$ & 5714 & 0.73 & 0.44 & 0 & 0 & 1 & 1 & 1 \\
\hline PRI_PERCENT & 7384 & 17.93 & 17.24 & 0 & 5.07 & 12.19 & 26.13 & 96.75 \\
\hline INV_HORIZON & 7384 & 8.25 & 3.47 & 0 & 5.72 & 8.34 & 10.76 & 18.26 \\
\hline
\end{tabular}


Table 2 (continued)

\begin{tabular}{llllllllll}
\hline Variables & N & Mean & SD & \multicolumn{2}{l}{ Quantiles } & & \\
\cline { 5 - 8 } & & & & & Min & 0.25 & Median & 0.75 & Max \\
\hline SIZE & 7384 & 22.61 & 1.86 & 14.27 & 21.32 & 22.38 & 23.76 & 28.55 \\
DEBT_RATIO & 7384 & 0.24 & 0.18 & 0 & 0.11 & 0.22 & 0.34 & 2.45 \\
TANGIBILITY & 7384 & 0.23 & 0.23 & -0.23 & 0.03 & 0.16 & 0.36 & 1.16 \\
Q & 7384 & 1.19 & 2.04 & -1.03 & 0.56 & 0.87 & 1.36 & 90.07 \\
ROA & 7384 & 4.54 & 7.46 & -27.93 & 0.84 & 3.9 & 7.68 & 32.66 \\
VOLA & 7384 & 0.36 & 0.19 & 0.05 & 0.24 & 0.3 & 0.41 & 2.77 \\
ANALYST & 7384 & 2.65 & 0.77 & 0 & 2.3 & 2.83 & 3.18 & 3.99 \\
FREE_FLOAT & 7384 & 74.95 & 25.11 & 0.1 & 54.56 & 84.02 & 97.69 & 100 \\
DJSI_EU & 7384 & 0.13 & 0.33 & 0 & 0 & 0 & 0 & 1 \\
BGD & 7384 & 17 & 12.85 & 0 & 7.69 & 16.26 & 25 & 66.67 \\
BSIZE & 7384 & 11.07 & 4.19 & 1 & 8 & 10 & 13 & 38 \\
\hline
\end{tabular}

by E_PILLAR. In support of hypothesis $1 \mathrm{a}$, we find that the presence of socially responsible investors is, in fact, positively associated with overall environmental performance. Depending on the model specification, we find positive and significant coefficients of PRI_PERCENT between 0.072 and 0.117 ( $p$-values $=0.000$ across all models). Supporting our first hypothesis, these findings provide evidence that the monitoring function of invested UN PRI signatories leads to greater corporate efforts to engage in environmentally friendly activities and policies.

Regarding hypothesis $2 \mathrm{a}$, we also find a positive association with E_PILLAR. Long-term institutional investors are also linked to better environmental performance by invested firms. Depending on the model specification, the coefficients of INV_HORIZON are between 0.361 and 0.824 (p-values $=0.000$ across all models).

For hypotheses $1 \mathrm{~b}$ and $2 \mathrm{~b}$, we took a more fine-grained, disaggregated perspective on firms' environmental performance by using the firms' environmental category scores for EMS, RES and INNO as dependent variables. Across all dimensions, as presented in Table 5, we consistently find that sustainable institutional investor ownership is associated with higher category scores. The results indicate that these investors have a broad impact on the invested firms' environmental engagement, which is not confined to specific operational areas or single environmental key performance indexes.

Finally, testing the third hypothesis, we analyze whether the propensity of responding to the CDP survey is greater for firms with greater ownership of sustainable institutional investors. The results of the logistic regression are presented in Table 6. Confirming our previous results, we find that our two sustainable institutional investor proxies increase the probability of responding to the CDP survey. With each percentage increase of UN PRI signatories, the likelihood of responding increases by approximately $1.2 \%$. This likelihood also increases regarding investor long-termism: each value of INV_HORIZON increases the likelihood of responding to the survey by approximately $8.1 \%$. 


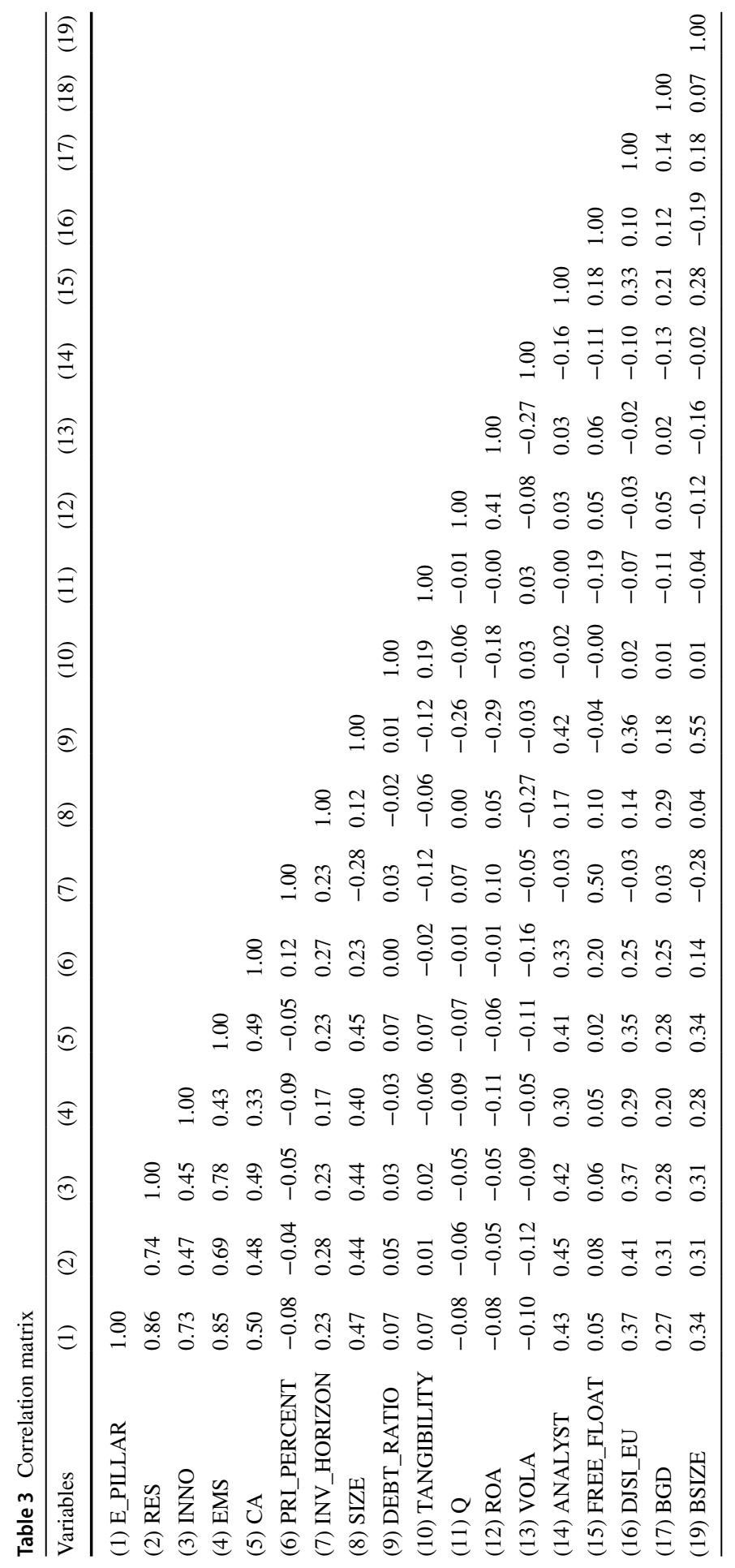


Table 4 Sustainable institutional investors and firms' environmental performance (E_PILLAR)

\begin{tabular}{|c|c|c|c|c|c|c|}
\hline Variables & (Model 1) & (Model 2) & (Model 3) & (Model 4) & (Model 5) & (Model 6) \\
\hline \multirow{2}{*}{$\begin{array}{l}\text { PRI_PER- } \\
\text { CENT }\end{array}$} & $0.072 * * *$ & $0.117 * * *$ & $0.101 * * *$ & & & \\
\hline & $(0.017)$ & $(0.016)$ & $(0.019)$ & & & \\
\hline \multirow{2}{*}{$\begin{array}{l}\text { INV_HORI- } \\
\text { ZON }\end{array}$} & & & & $0.824 * * *$ & $0.675 * * *$ & $0.361 * * *$ \\
\hline & & & & $(0.089)$ & $(0.086)$ & $(0.090)$ \\
\hline \multirow[t]{2}{*}{ SIZE } & $4.119 * * *$ & $6.778 * * *$ & $7.448 * * *$ & $3.915 * * *$ & $6.363 * * *$ & $7.147 * * *$ \\
\hline & $(0.182)$ & $(0.206)$ & $(0.217)$ & $(0.178)$ & $(0.204)$ & $(0.221)$ \\
\hline \multirow{2}{*}{$\begin{array}{l}\text { DEBT }_{-} \\
\text {RATIO }\end{array}$} & $5.183 * * *$ & -2.007 & $-5.023 * * *$ & $5.385^{* * *}$ & -1.594 & $-4.558 * * *$ \\
\hline & $(1.521)$ & (1.409) & $(1.393)$ & $(1.464)$ & $(1.403)$ & (1.389) \\
\hline \multirow{2}{*}{$\begin{array}{l}\text { TANGIBIL- } \\
\text { ITY }\end{array}$} & $15.191 * * *$ & 0.138 & $3.239 * *$ & $15.120 * * *$ & 0.278 & $3.051 *$ \\
\hline & $(1.212)$ & $(1.662)$ & $(1.627)$ & (1.208) & (1.641) & (1.619) \\
\hline \multirow[t]{2}{*}{ Q } & -0.043 & -0.014 & 0.015 & -0.013 & -0.009 & 0.005 \\
\hline & $(0.065)$ & $(0.068)$ & $(0.065)$ & $(0.065)$ & $(0.068)$ & $(0.064)$ \\
\hline \multirow[t]{2}{*}{ ROA } & -0.032 & -0.040 & 0.002 & -0.033 & -0.033 & 0.004 \\
\hline & $(0.038)$ & $(0.037)$ & $(0.036)$ & $(0.038)$ & $(0.036)$ & $(0.036)$ \\
\hline \multirow[t]{2}{*}{ VOLA } & $-6.110 * * *$ & -0.775 & 0.791 & $-3.146^{*}$ & 1.216 & 1.916 \\
\hline & (1.746) & (1.710) & (1.736) & (1.799) & $(1.745)$ & (1.777) \\
\hline \multirow[t]{2}{*}{ ANALYST } & $8.345^{* * * *}$ & $6.894 * * *$ & $5.042 * * *$ & $8.005^{* * *}$ & $6.753 * * *$ & $5.106 * * *$ \\
\hline & $(0.457)$ & $(0.451)$ & $(0.482)$ & $(0.458)$ & $(0.451)$ & $(0.482)$ \\
\hline \multirow{2}{*}{$\begin{array}{l}\text { FREE_- } \\
\text { FLOAT }\end{array}$} & 0.011 & -0.003 & $-0.021^{*}$ & $0.024 * *$ & $0.022 * *$ & -0.003 \\
\hline & $(0.012)$ & $(0.011)$ & $(0.012)$ & $(0.011)$ & $(0.010)$ & $(0.011)$ \\
\hline \multirow[t]{2}{*}{ DJSI_EU } & $13.488 * * *$ & $10.063 * * *$ & $9.021 * * *$ & $12.980 * * *$ & $9.796 * * *$ & $8.911 * * *$ \\
\hline & $(0.692)$ & $(0.648)$ & $(0.657)$ & $(0.691)$ & $(0.646)$ & $(0.659)$ \\
\hline \multirow[t]{2}{*}{ BGD } & $0.270 * * *$ & $0.285^{* * *}$ & $0.199 * * *$ & $0.247 * * *$ & $0.267 * * *$ & $0.197 * * *$ \\
\hline & $(0.022)$ & $(0.021)$ & $(0.024)$ & $(0.022)$ & $(0.020)$ & $(0.024)$ \\
\hline \multirow[t]{2}{*}{ BSIZE } & $0.643 * * *$ & $0.600 * * *$ & $0.523 * * *$ & $0.639 * * *$ & $0.583 * * *$ & $0.528 * * *$ \\
\hline & $(0.080)$ & $(0.076)$ & $(0.090)$ & $(0.080)$ & $(0.077)$ & $(0.090)$ \\
\hline \multirow[t]{2}{*}{ Constant } & $-82.029 * * *$ & $-127.635^{* * *}$ & $-137.702 * * *$ & $-82.057 * * *$ & $-121.814 * * *$ & $-134.110^{* * *}$ \\
\hline & $(3.891)$ & $(4.616)$ & $(4.922)$ & $(3.861)$ & $(4.540)$ & $(4.952)$ \\
\hline Observations & 7384 & 7384 & 7384 & 7384 & 7384 & 7384 \\
\hline R-squared & 0.367 & 0.495 & 0.527 & 0.373 & 0.496 & 0.526 \\
\hline Industry FE & NO & YES & YES & NO & YES & YES \\
\hline Country FE & NO & NO & YES & NO & NO & YES \\
\hline Year FE & YES & YES & YES & YES & YES & YES \\
\hline
\end{tabular}

All models use the environmental pillar score (E_PILLAR) as the dependent variable. Robust standard errors in parentheses. $*, * *$ and $* * *$ denote significance at the $10 \%, 5 \%$ and $1 \%$ level 
Table 5 Sustainable institutional investors and subcategories of environmental performance (EMS, INNO and RES)

\begin{tabular}{|c|c|c|c|c|c|c|}
\hline Variables & (Model 1) & (Model 2) & (Model 3) & (Model 4) & (Model 5) & (Model 6) \\
\hline \multicolumn{7}{|c|}{ Panel A: Emissions reduction category score (EMS) } \\
\hline PRI_PERCENT & $\begin{array}{l}0.165^{* * * *} \\
(0.020)\end{array}$ & $\begin{array}{l}0.173 * * * \\
(0.020)\end{array}$ & $\begin{array}{l}0.109 * * * \\
(0.023)\end{array}$ & & & \\
\hline INV_HORIZON & & & & $\begin{array}{l}0.982 * * * \\
(0.102)\end{array}$ & $\begin{array}{l}0.960 * * * \\
(0.101)\end{array}$ & $\begin{array}{l}0.558 * * * \\
(0.105)\end{array}$ \\
\hline Controls & YES & YES & YES & YES & YES & YES \\
\hline Constant & YES & YES & YES & YES & YES & YES \\
\hline Observations & 7384 & 7384 & 7384 & 7384 & 7384 & 7384 \\
\hline R-squared & 0.344 & 0.427 & 0.469 & 0.347 & 0.428 & 0.469 \\
\hline Industry FE & NO & YES & YES & NO & YES & YES \\
\hline Country FE & NO & NO & YES & NO & NO & YES \\
\hline Year FE & YES & YES & YES & YES & YES & YES \\
\hline \multicolumn{7}{|c|}{ Panel B: Product innovations category score (INNO) } \\
\hline PRI_PERCENT & $\begin{array}{l}-0.021 \\
(0.022)\end{array}$ & $\begin{array}{l}0.038^{*} \\
(0.022)\end{array}$ & $\begin{array}{l}0.089 * * * \\
(0.025)\end{array}$ & & & \\
\hline INV_HORIZON & & & & $\begin{array}{l}0.661 * * * \\
(0.117)\end{array}$ & $\begin{array}{l}0.418 * * * \\
(0.114)\end{array}$ & $\begin{array}{l}0.297 * * \\
(0.121)\end{array}$ \\
\hline Controls & YES & YES & YES & YES & YES & YES \\
\hline Constant & YES & YES & YES & YES & YES & YES \\
\hline Observations & 7290 & 7290 & 7290 & 7290 & 7290 & 7290 \\
\hline R-squared & 0.221 & 0.365 & 0.389 & 0.224 & 0.366 & 0.388 \\
\hline Industry FE & NO & YES & YES & NO & YES & YES \\
\hline Country FE & NO & NO & YES & NO & $\mathrm{NO}$ & YES \\
\hline Year FE & YES & YES & YES & YES & YES & YES \\
\hline \multicolumn{7}{|c|}{ Panel C: Resource use category score (RES) } \\
\hline PRI_PERCENT & $\begin{array}{l}0.116 * * * \\
(0.020)\end{array}$ & $\begin{array}{l}0.142 * * * \\
(0.020)\end{array}$ & $\begin{array}{l}0.106 * * * \\
(0.024)\end{array}$ & & & \\
\hline INV_HORIZON & & & & $\begin{array}{l}0.920 * * * \\
(0.105)\end{array}$ & $\begin{array}{l}0.766^{* * *} \\
(0.102)\end{array}$ & $\begin{array}{l}0.421 * * * \\
(0.109)\end{array}$ \\
\hline Controls & YES & YES & YES & YES & YES & YES \\
\hline Constant & YES & YES & YES & YES & YES & YES \\
\hline Observations & 7374 & 7374 & 7374 & 7374 & 7374 & 7374 \\
\hline R-squared & 0.334 & 0.425 & 0.456 & 0.339 & 0.426 & 0.456 \\
\hline Industry FE & NO & YES & YES & NO & YES & YES \\
\hline Country FE & NO & NO & YES & NO & NO & YES \\
\hline Year FE & YES & YES & YES & YES & YES & YES \\
\hline
\end{tabular}

All models of panel A use the emissions reduction category score (EMS) as the dependent variable. All models of panel B use the product innovations category score (INNO) as the dependent variable. All models of panel $\mathrm{C}$ use the resource use category score (RES) as the dependent variable. Robust standard errors in parentheses. $*$, ** and $* * *$ denote significance at the $10 \%, 5 \%$ and $1 \%$ level 
Table 6 Sustainable institutional investors and firms' carbon risk awareness (CA)

\begin{tabular}{|c|c|c|c|c|c|c|}
\hline Variables & (Model 1) & (Model 2) & (Model 3) & (Model 4) & (Model 5) & (Model 6) \\
\hline PRI_PERCENT & $\begin{array}{l}0.019 * * * \\
(0.003)\end{array}$ & $\begin{array}{l}0.022^{* * * *} \\
(0.003)\end{array}$ & $\begin{array}{l}0.012^{* * * *} \\
(0.003)\end{array}$ & & & \\
\hline INV_HORIZON & & & & $\begin{array}{l}0.135 * * * \\
(0.011)\end{array}$ & $\begin{array}{l}0.136 * * * \\
(0.012)\end{array}$ & $\begin{array}{l}0.081 * * * \\
(0.014)\end{array}$ \\
\hline SIZE & $\begin{array}{l}0.229 * * * \\
(0.029)\end{array}$ & $\begin{array}{l}0.430 * * * \\
(0.035)\end{array}$ & $\begin{array}{l}0.603 * * * \\
(0.043)\end{array}$ & $\begin{array}{l}0.187 * * * \\
(0.028)\end{array}$ & $\begin{array}{l}0.363 * * * \\
(0.035)\end{array}$ & $\begin{array}{l}0.557 * * * \\
(0.044)\end{array}$ \\
\hline DEBT_RATIO & $\begin{array}{l}-0.407 * * \\
(0.198)\end{array}$ & $\begin{array}{l}-0.859 * * * \\
(0.217)\end{array}$ & $\begin{array}{l}-1.222 * * * \\
(0.253)\end{array}$ & $\begin{array}{l}-0.219 \\
(0.183)\end{array}$ & $\begin{array}{l}-0.677 * * * \\
(0.219)\end{array}$ & $\begin{array}{l}-1.153 * * * \\
(0.260)\end{array}$ \\
\hline TANGIBILITY & $\begin{array}{l}0.618^{* * * *} \\
(0.158)\end{array}$ & $\begin{array}{l}0.286 \\
(0.236)\end{array}$ & $\begin{array}{l}0.793 * * * \\
(0.269)\end{array}$ & $\begin{array}{l}0.594 * * * \\
(0.157)\end{array}$ & $\begin{array}{l}0.357 \\
(0.238)\end{array}$ & $\begin{array}{l}0.787 * * * \\
(0.267)\end{array}$ \\
\hline Q & $\begin{array}{l}0.032 \\
(0.041)\end{array}$ & $\begin{array}{l}0.047 \\
(0.051)\end{array}$ & $\begin{array}{l}0.041 \\
(0.038)\end{array}$ & $\begin{array}{l}0.036 \\
(0.040)\end{array}$ & $\begin{array}{l}0.052 \\
(0.053)\end{array}$ & $\begin{array}{l}0.045 \\
(0.042)\end{array}$ \\
\hline ROA & $\begin{array}{l}-0.006 \\
(0.007)\end{array}$ & $\begin{array}{l}-0.003 \\
(0.007)\end{array}$ & $\begin{array}{l}0.002 \\
(0.007)\end{array}$ & $\begin{array}{l}-0.005 \\
(0.006)\end{array}$ & $\begin{array}{l}-0.001 \\
(0.007)\end{array}$ & $\begin{array}{l}0.001 \\
(0.007)\end{array}$ \\
\hline VOLA & $\begin{array}{l}-1.397 * * * \\
(0.239)\end{array}$ & $\begin{array}{l}-0.973 * * * \\
(0.274)\end{array}$ & $\begin{array}{l}-1.036 * * * \\
(0.299)\end{array}$ & $\begin{array}{l}-0.834 * * * \\
(0.252)\end{array}$ & $\begin{array}{l}-0.432 \\
(0.279)\end{array}$ & $\begin{array}{l}-0.758 * * \\
(0.302)\end{array}$ \\
\hline ANALYST & $\begin{array}{l}0.555 * * * \\
(0.055)\end{array}$ & $\begin{array}{l}0.465 * * * \\
(0.059)\end{array}$ & $\begin{array}{l}0.347 * * * \\
(0.067)\end{array}$ & $\begin{array}{l}0.530 * * * \\
(0.057)\end{array}$ & $\begin{array}{l}0.442 * * * \\
(0.060)\end{array}$ & $\begin{array}{l}0.352 * * * \\
(0.067)\end{array}$ \\
\hline FREE_FLOAT & $\begin{array}{l}0.010 * * * \\
(0.002)\end{array}$ & $\begin{array}{l}0.008 * * * \\
(0.002)\end{array}$ & $\begin{array}{l}0.001 \\
(0.002)\end{array}$ & $\begin{array}{l}0.015 * * * \\
(0.001)\end{array}$ & $\begin{array}{l}0.014 * * * \\
(0.002)\end{array}$ & $\begin{array}{l}0.004 * * \\
(0.002)\end{array}$ \\
\hline DJSI_EU & $\begin{array}{l}1.892 * * * \\
(0.212)\end{array}$ & $\begin{array}{l}1.792 * * * \\
(0.218)\end{array}$ & $\begin{array}{l}1.579 * * * \\
(0.219)\end{array}$ & $\begin{array}{l}1.855 * * * \\
(0.216)\end{array}$ & $\begin{array}{l}1.762 * * * \\
(0.221)\end{array}$ & $\begin{array}{l}1.552^{* * * *} \\
(0.219)\end{array}$ \\
\hline BGD & $\begin{array}{l}0.028 * * * \\
(0.003)\end{array}$ & $\begin{array}{l}0.027 * * * \\
(0.003)\end{array}$ & $\begin{array}{l}0.017 * * * \\
(0.004)\end{array}$ & $\begin{array}{l}0.025 * * * \\
(0.003)\end{array}$ & $\begin{array}{l}0.024 * * * \\
(0.003)\end{array}$ & $\begin{array}{l}0.017 * * * \\
(0.004)\end{array}$ \\
\hline BSIZE & $\begin{array}{l}0.022 * * \\
(0.011)\end{array}$ & $\begin{array}{l}0.023 * * \\
(0.011)\end{array}$ & $\begin{array}{l}0.018 \\
(0.014)\end{array}$ & $\begin{array}{l}0.017 \\
(0.011)\end{array}$ & $\begin{array}{l}0.017 \\
(0.011)\end{array}$ & $\begin{array}{l}0.016 \\
(0.014)\end{array}$ \\
\hline Constant & $\begin{array}{l}-6.361 * * * \\
(0.634)\end{array}$ & $\begin{array}{l}-11.212 * * * \\
(0.822)\end{array}$ & $\begin{array}{l}-14.531 * * * \\
(1.031)\end{array}$ & $\begin{array}{l}-6.638 * * * \\
(0.634)\end{array}$ & $\begin{array}{l}-10.863^{* * *} \\
(0.824)\end{array}$ & $\begin{array}{l}-14.223 * * * \\
(1.039)\end{array}$ \\
\hline Observations & 5,714 & 5,636 & 5,626 & 5,714 & 5,636 & 5,626 \\
\hline Pseudo r-squared & 0.189 & 0.245 & 0.301 & 0.202 & 0.254 & 0.305 \\
\hline Industry FE & $\mathrm{NO}$ & YES & YES & $\mathrm{NO}$ & YES & YES \\
\hline Country FE & NO & $\mathrm{NO}$ & YES & $\mathrm{NO}$ & NO & YES \\
\hline Year FE & YES & YES & YES & YES & YES & YES \\
\hline
\end{tabular}

All models use carbon risk awareness (CA) as the dependent variable. Robust standard errors in parentheses. $*$, $* *$ and $* * *$ denote significance at the $10 \%, 5 \%$ and $1 \%$ level

Throughout this paper, we employ various panel data methods to mitigate the endogeneity concerns inherent in this line of research. Without a distinct exogeneous shock that could be utilized for a quasi-natural experiment, we can hardly establish causality. These concerns remain even though we show consistent results across multiple estimations based on variables from various data sources. To further mitigate endogeneity concerns, we apply a two-stage least squares instrumental variable 
design. To do this, we construct industry-year averages for our primary variables for socially responsible investors (PRI_PERCENT) and long-term institutional investors (INV_HORIZON). These averages exclude the focal firm of analysis and are therefore regarded as exogeneous to that firm's environmental performance (E_PILLAR). We also exclude any industry-year combinations with fewer than 10 observations. The untabulated results are entirely in line with our previous analysis. The secondstage coefficients for PRI_PERCENT (0.530) and INV_HORZON (0.715) are positive and statistically significant ( $p$-values $=0.000$ ). Postestimation analysis confirms the strength and relevance of our instruments.

\section{Discussion}

\subsection{Synthesis of results}

Based on an agency-theoretical framework and relying on a European sample of 7384 firm-year observations between 2008 and 2017, we hypothesized and find that our two proxies of sustainable institutional investors have a positive impact on both environmental performance and carbon awareness. In more detail, in line with our first hypothesis, content-driven, socially responsible investors who sign the UN PRI are linked with increased firm environmental performance and its three sub-pillars. These results are in line with prior studies (Dyck et al. 2019; Kim et al. 2019b; Alda 2019). Dyck et al. (2019) find a positive impact of institutional investors on environmental and social performance based on an international sample. According to Kim et al. (2019b), local, socially responsible investment funds reduce the total quantity of toxic chemicals, assuming a positive impact on environmental performance in the US capital market. Alda (2019) finds that UK pension funds positively impact the environmental performance of the investee firms. Moreover, in line with the second hypothesis, time-driven, long-term investors also lead to increased firm environmental performance and its three sub-pillars. Our results complement prior studies on the US capital markets on the positive impact of long-term investors on overall ESG performance (Meng and Wang 2020; Erhemjamts and Huang 2019; Fu et al. 2019; Gloßner 2019; Kim et al. 2019a; Lamb and Butler 2018; Boubaker et al. 2017; Neubaum and Zahra 2006). Finally, in line with the third hypothesis, the analysis shows that the two proxies of sustainable ownership are also positively associated with firms' carbon awareness, proxied by their willingness to respond to the CDP survey. These research results complement Alda (2019), who reports a positive impact of socially responsible pension funds on carbon performance.

\subsection{Theoretical contributions and implications}

This study has relevant theoretical contributions and practical implications. First, in contrast to classical principal agent theory, institutional investors cannot be classified as a homogeneous shareholder group. Instead, with regard to their preferences and nature, a separation between short-term and long-term on the one hand and 
financial and non-financial (sustainable) investors on the other hand is necessary. Second, in contrast to traditional agency theory, institutional investors' preferences are not just focussed on financial performance. Environmental (climate) risks and opportunities should be properly evaluated and included in investment decisions with regard to disruptive business models and increased climate change regulations and societal expectations. Because financial and ESG aspects should be classified as integrative risks and opportunities in decision-making, the goal of sustainable institutional investors as a key external corporate governance tool is to strengthen the financial and non-financial performance of the corporation. As a result, classical agency theory, related shareholder value concepts and corporate governance mechanisms should be complemented by environmental and social aspects. This leads to sustainable corporate governance and stakeholder-oriented management theories (e.g., stakeholder (agency) theory) as a fruitful business case theorem (Schaltegger et al. 2019) for ESG issues.

\subsection{Implications for practice}

Our research has important implications for business practice. First, our results imply that sustainable institutional investors may put pressure on top managers to change their environmental management in order to increase environmental performance. Thus, there may be an increased extrinsic motivation for top managers to analyze their business models and their risk management systems in order to contribute to climate change policies. If listed corporations are not successful in their environmental efforts, firm reputations may be impaired, and sustainable institutional investors are likely to use their exit or voice options. They may punish the company by increased risk premia for their invested capital, leading to a lower firm valuation. Second, with regard to regulatory issues, the current European regulations on 'carbon finance' (e.g., the taxonomy regulation or the disclosure directive) will strengthen the increased awareness of institutional investors of environmental risks and opportunities in the following years. Greater voting power of sustainable institutional investors in European companies can be linked to more sustainable business practices across multiple dimensions, including resource use, product innovation, emissions reductions and carbon awareness. This suggests that institutional investors are capable of granularly evaluating the environmental activities of the invested firms. Additional disclosure requirements on the level of single economic activities, such as taxonomy regulations (EU 2020/852), may further enhance these observed dynamics. Concomitantly, the sustainable finance disclosure regulation (EU 2019/2088) improves the information availability for retail investors regarding the environmental characteristics of sustainable investments. These important developments on the regulatory front accompany the ongoing trend towards sustainable investing as witnessed by the unprecedented increase of assets under managements by large institutional investors who are signatories to the UN PRI. The alignment of interests between institutional investors and other stakeholders of the firm can help to achieve milestone objectives to transform the European economy into a more 
sustainable, resilient and circular system. For example, the European Commission has set a GHG reduction target of $55 \%$ for 2030 and developed a climate law to achieve climate neutrality by 2050 . The monitoring function and investment decisions of sustainable institutional investors could be essential pieces to achieve these ambitious objectives. The increased comparability and reliability of ESG ratings and classifications of environmentally friendly business activities are likely to further promote the inclusion of environmental ratings in investment decisions in the future.

\subsection{Limitations and future research directions}

Although this study provides novel and interesting findings, some limitations should be highlighted. First, a generalizable conclusion about the drivers and advantageousness of an investment in the improvement of a firm's environmental performance cannot be drawn because each firm has a different optimal level that individually determines whether a certain investment creates or destroys firm value. Apart from this, investors possess individual, multi-attributed value functions regarding firms' financial and non-financial performance. Based on this, socially responsible investors may even forego financial gains for 'ethical dividends', making the relationship between a company's share of institutional investors and the optimal level of environmental performance multidimensional and dynamic. Second, although we focus on a very relevant and heterogeneous sample, some findings may not be generalizable to other systems. Third, alternative proxies of environmental performance are required in order to offer convergent validity to our results. Finally, even though we are able to identify an isomorphism related to sustainable institutional investors and environmental performance, we are not able to extract its origin. This origin could either be coercive due to recent regulatory changes within the EU, normative due to the investors' substantial commitment to environmental improvements or simply mimetic. One factor that additionally influences this isomorphism is the strong influence of proxy advisors on the investment decisions of institutional investors (McCahery et al. 2016). The relationship of proxy advisors and ESG performance has not yet been examined (Copland et al. 2018). Since the updated shareholder rights directive enhances the transparency of proxy voting and also applies to non-EU proxy advisors who carry out their activities through an establishment in the EU, this indicates a useful starting point for future research (EU 2017/828).

Furthermore, we do not differentiate between the individual monitoring efforts of UN PRI signatories because these are not observable. This limitation provides a basis for future research and may be investigated in more detail by means of surveys or case studies in order to develop an even more differentiated understanding of the impact of sustainable institutional investors. In that regard, the evolving integration of ESG-contingent components in executive compensation may additionally be influenced by investors via their increased say-on-pay voting rights within the European member states. The resulting dynamics in terms of institutional investor influence, top management compensation structure and ESG performance have not been sufficiently considered within research so far and may thus be a good starting point for future investigations (Winschel and Stawinoga 2019). 


\subsection{Conclusions}

This study addresses the impact of the nature of institutional ownership on firms' environmental performance from a European perspective. Institutional investors may possess individual, multi-attributed value functions regarding a firm's financial and environmental performance, which has not yet been sufficiently considered in extant research (Faller and Knyphausen-Aufseß, 2018). Hence, this paper investigates the effects of two specific aspects of sustainable institutional investors (content-related, socially responsible investors and time-driven, long-term institutional investors) on total environmental performance and related sub-pillars. Sustainable institutional investors are expected to promote environmental investments and integrate sustainability. Prior studies do not include both time-driven and content-related aspects of sustainable institutional ownership in their research designs. Moreover, in view of its major international relevance, the US capital market has been mainly used in prior studies. Due to recent regulatory changes and discussions on climate change policy (e.g., the current EU green deal project and related regulations on carbon finance), we specifically focus on a cross-national European sample consisting of 7384 firm-year observations between 2008 and 2017. In line with our three hypotheses, both socially responsible investors and long-term institutional investors are significantly positively related to various dimensions of firms' environmental performance. In more detail, sustainable institutional ownership leads to increased total environmental performance, including its three sub-pillars, and to increased carbon awareness. This study has important implications not only for future research but also for business practice and regulatory bodies. Institutional investors' awareness of environmental issues is likely to further increase in the future due to current European regulations on green finance. Arguably, stricter regulations on green finance are necessary in order to reach the main goals of the Paris Agreement of 2016 and to realize a climate neutral economy by 2050 .

Author contributions All authors contributed to the study conception and design. All authors read and approved the final manuscript.

Funding Open Access funding enabled and organized by Projekt DEAL. The authors received no funding for this research.

Data availability All data is available from the sources cited in the manuscript.

Code availability Upon request, the code for this study is available from the authors.

\section{Declarations}

Conflict of interest The authors declare that they have no conflict of interest.

Open Access This article is licensed under a Creative Commons Attribution 4.0 International License, which permits use, sharing, adaptation, distribution and reproduction in any medium or format, as long as you give appropriate credit to the original author(s) and the source, provide a link to the Creative Commons licence, and indicate if changes were made. The images or other third party material in this article are included in the article's Creative Commons licence, unless indicated otherwise in a credit line to the 
material. If material is not included in the article's Creative Commons licence and your intended use is not permitted by statutory regulation or exceeds the permitted use, you will need to obtain permission directly from the copyright holder. To view a copy of this licence, visit http://creativecommons.org/licenses/by/4.0/.

\section{References}

Aghion P, van Reenen J, Zingales L (2013) Innovation and institutional ownership. Am Econ Rev 103:277-304. https://doi.org/10.1257/aer.103.1.277

Ainsworth A, Corbett A, Satchell S (2018) Psychic dividends of socially responsible investment portfolios. J Asset Manag 19:179-190. https://doi.org/10.1057/s41260-017-0073-4

Akbaş H, Canikli S (2019) Determinants of voluntary greenhouse gas emission disclosure: an empirical investigation on Turkish firms. Sustainability 11:107. https://doi.org/10.3390/su11010107

Alda M (2019) Corporate sustainability and institutional shareholders. Bus Strateg Environ 28:1060-1071

Barnea A, Rubin A (2010) Corporate social responsibility as a conflict between shareholders. J Bus Ethics $97: 71-86$

Barrot J-N (2012) Investor horizon and innovation: evidence from private equity funds. SSRN Journal

Bebchuk LA, Cohen A, Hirst S (2017) The agency problems of institutional investors. J Econ Perspect 31:89-112. https://doi.org/10.1257/jep.31.3.89

Boubaker S, Chourou L, Himick D, Saadi S (2017) It's about time! The influence of institutional investment horizon on corporate social responsibility. Thunderbird Int Bus Rev 59:571-594

Busch T, Friede G (2018) The robustness of the corporate social and financial performance relation: a second-order meta-analysis. Corp Soc Responsib Environ Manag 25:583-608

Bushee BJ (1998) The influence of institutional investors on myopic R\&D investment behavior. Account Rev 305-333

Bushee BJ (2001) Do institutional investors prefer near-term earnings over long-run value? Contemp Account Res 18:207-246. https://doi.org/10.1506/J4GU-BHWH-8HME-LE0X

Cabeza-García L, Fernández-Gago R, Nieto M (2018) Do board gender diversity and director typology impact CSR reporting? Eur Manag Rev 15:559-575. https://doi.org/10.1111/emre.12143

Calza F, Profumo G, Tutore I (2016) Corporate ownership and environmental proactivity. Bus Strat Env 25:369-389. https://doi.org/10.1002/bse.1873

Carroll AB, Shabana KM (2010) The business case for corporate social responsibility: a review of concepts, research and practice. Int J Manag Rev 12:85-105. https://doi.org/10.1111/j.14682370.2009.00275.x

Cespa G, Cestone G (2007) Corporate social responsibility and managerial entrenchment. J Econ Manag Strategy 16:741-771. https://doi.org/10.1111/j.1530-9134.2007.00156.x

Chava S (2014) Environmental externalities and cost of capital. Manag Sci 60:2223-2247. https://doi. org/10.1287/mnsc.2013.1863

Chen X, Harford J, Li K (2007) Monitoring: which institutions matter? J Financ Econ 86:279-305. https://doi.org/10.1016/j.jfineco.2006.09.005

Clark CE, Crawford EP (2012) Influencing climate change policy. Bus Soc 51:148-175. https://doi. org/10.1177/0007650311427594

Copland J, Larcker DF, Tayan B (2018) The big thumb on the scale: an overview of the proxy advisory industry

Cumming D, Johan S (2007) Socially responsible institutional investment in private equity. J Bus Ethics 75:395-416. https://doi.org/10.1007/s10551-006-9261-8

Dam L, Scholtens B (2012) Does ownership type matter for corporate social responsibility? Corp Gov 20:233-252. https://doi.org/10.1111/j.1467-8683.2011.00907.x

Dyck A, Lins KV, Roth L, Wagner HF (2019) Do institutional investors drive corporate social responsibility? International evidence. J Financ Econ 131:693-714. https://doi.org/10.1016/j.jfineco. 2018.08.013

Erhemjamts O, Huang K (2019) Institutional ownership horizon, corporate social responsibility and shareholder value. J Bus Res 105:61-79

Escrig-Olmedo E, Muñoz-Torres MJ, Fernández-Izquierdo MÁ, Rivera-Lirio JM (2014) Lights and shadows on sustainability rating scoring. Rev Manag Sci 8:559-574. https://doi.org/10.1007/ s11846-013-0118-0 
Escrig-Olmedo E, Rivera-Lirio JM, Muñoz-Torres MJ, Fernández-Izquierdo MÁ (2017) Integrating multiple ESG investors' preferences into sustainable investment: a fuzzy multicriteria methodological approach. J Clean Prod 162:1334-1345. https://doi.org/10.1016/j.jclepro.2017.06.143

European Union (2017) Directive (EU) 2017/828 of the European Parliament and of the Council of 17 May 2017 amending Directive 2007/36/EC as regards the encouragement of long-term shareholder engagement (Text with EEA relevance)

European Union (2019) Regulation (EU) 2019/2088 of the European Parliament and of the Council of 27 November 2019 on sustainability-related disclosures in the financial services sector (Text with EEA relevance)

European Union (2020) Regulation (EU) 2020/852 of the European Parliament and of the Council of 18 June 2020 on the establishment of a framework to facilitate sustainable investment, and amending Regulation (EU) 2019/2088

Faller CM, Knyphausen-Aufseß D (2018) Does equity ownership matter for corporate social responsibility? A literature review of theories and recent empirical findings. J Bus Ethics 150:15-40

Feldman SJ, Soyka PA, Ameer PG (1997) Does improving a firm's environmental management system and environmental performance result in a higher stock price? JOI 6:87-97. https://doi.org/10.3905/ joi.1997.87

Fu X, Tang T, Yan X (2019) Why do institutions like corporate social responsibility investments? J Empir Financ 51:44-63

Galbreath J (2018) Is board gender diversity linked to financial performance? The mediating mechanism of CSR. Bus Soc 57:863-889. https://doi.org/10.1177/0007650316647967

Gaspar J-M, Massa M, Matos P (2005) Shareholder investment horizons and the market for corporate control. J Financ Econ 76:135-165. https://doi.org/10.1016/j.jfineco.2004.10.002

Gaspar J-M, Massa M, Matos P, Patgiri R, Rehman Z (2013) Payout policy choices and shareholder investment horizons*. Rev Finance 17:261-320. https://doi.org/10.1093/rof/rfr040

Gibson R, Glossner S, Krueger P, Matos P, Steffen T (2020) Responsible institutional investing around the world. SSRN J. https://doi.org/10.2139/ssrn.3525530

Gillan SL, Starks LT (2000) Corporate governance proposals and shareholder activism: the role of institutional investors. J Financ Econ 57:275-305

Gloßner S (2019) Investor horizons, long-term blockholders, and corporate social responsibility. J Bank Finance 103:78-97. https://doi.org/10.1016/j.jbankfin.2019.03.020

Gond J-P, Piani V (2013) Enabling institutional investors' collective action. Bus Soc 52:64-104. https:// doi.org/10.1177/0007650312460012

Graves SB, Waddock SA (1994) Institutional owners and corporate social performance. AMJ 37:10341046. https://doi.org/10.5465/256611

Harjoto MA, Jo H (2011) Corporate governance and CSR nexus. J Bus Ethics 100:45-67. https://doi.org/ 10.1007/s10551-011-0772-6

Hill CWL, Jones TM (1992) Stakeholder-agency theory. J Manag Stud 29:131-154

Hoffmann VH, Busch T (2008) Corporate carbon performance indicators. J Ind Ecol 12:505-520. https:// doi.org/10.1111/j.1530-9290.2008.00066.x

Hoq MZ, Mustaruddin S, Zubayer M, Mahmud KT (2010) The effect of CSR disclosure on institutional ownership. Pakistan Journal of Commerce and Social Sciences (PJCSS) 4:22-39UR - https://www. econstor.eu/handle/10419/187998

Ioannou I, Serafeim G (2015) The impact of corporate social responsibility on investment recommendations: analysts' perceptions and shifting institutional logics. Strateg Manag J 36:1053-1081. https:// doi.org/10.1002/smj.2268

Jaggi B, Allini A, Macchioni R, Zagaria C (2018) The factors motivating voluntary disclosure of carbon information: evidence based on Italian listed companies. Organ Environ 31:178-202. https://doi.org/ $10.1177 / 1086026617705282$

Jensen MC, Meckling WH (1976) Theory of the firm: managerial behavior, agency costs and ownership structure. J Financ Econ 3:305-360. https://doi.org/10.1016/0304-405X(76)90026-X

Jia M, Zhang Z (2013) Managerial ownership and corporate social performance: evidence from privately owned Chinese firms' response to the Sichuan earthquake. Corp Soc Responsib Environ Manag 20:257-274. https://doi.org/10.1002/csr.1289

Jiang H, Habib A (2009) The impact of different types of ownership concentration on annual report voluntary disclosures in New Zealand. Account Res J 22:275-304. https://doi.org/10.1108/1030961091 1005590 
Jung J, Herbohn K, Clarkson P (2018) Carbon risk, carbon risk awareness and the cost of debt financing. J Bus Ethics 150:1151-1171

Kim E-H, Lyon T (2011) When does institutional investor activism increase shareholder value? The carbon disclosure project. BE J Econ Anal Policy. https://doi.org/10.2202/1935-1682.2676

Kim H-D, Kim T, Kim Y, Park K (2019a) Do long-term institutional investors promote corporate social responsibility activities? J Bank Finance 101:256-269. https://doi.org/10.1016/j.jbankfin.2018.11. 015

Kim I, Wan H, Wang B, Yang T (2019b) Institutional investors and corporate environmental, social, and governance policies. Manag Sci 65:4901-4926

Kock CJ, Santaló J, Diestre L (2012) Corporate governance and the environment: what type of governance creates greener companies? J Manag Stud 49:492-514. https://doi.org/10.1111/j.1467-6486. 2010.00993.x

Kolk A, Levy D, Pinkse J (2008) Corporate responses in an emerging climate regime: the institutionalization and commensuration of carbon disclosure. Eur Account Rev 17:719-745. https://doi.org/10. 1080/09638180802489121

Kordsachia O (2020) A risk management perspective on CSR and the marginal cost of debt: empirical evidence from Europe. Rev Manag Sci. https://doi.org/10.1007/s11846-020-00392-2

Lamb NH, Butler FC (2018) The influence of family firms and institutional owners on corporate social responsibility performance. Bus Soc 57:1374-1406

Laurel-Fois D (2018) Beyond appearances: the risk-reducing effects of responsible investment practices. Bus Soc 57:826-862. https://doi.org/10.1177/0007650316635628

Li M, Dong L, Luan J, Wang P (2020) Do environmental regulations affect investors? Evidence from China's action plan for air pollution prevention. J Clean Prod 244:118817. https://doi.org/10.1016/j. jclepro.2019.118817

Liang HAO, Renneboog LUC (2017) On the foundations of corporate social responsibility. J Finance 72:853-910. https://doi.org/10.1111/jofi.12487

Lopatta K, Böttcher K, Lodhia SK, Tideman SA (2020) The relationship between gender diversity and employee representation at the board level and non-financial performance: a cross-country study. Int J Acc 55:2050001. https://doi.org/10.1142/S1094406020500018

Lourenço IC, Branco MC, Curto JD, Eugénio T (2012) How does the market value corporate sustainability performance? J Bus Ethics 108:417-428

Mahoney L, Roberts RW (2007) Corporate social performance, financial performance and institutional ownership in Canadian firms. Account Forum 31:233-253. https://doi.org/10.1016/j.accfor.2007.05. 001

Majoch AA, Andreas GF, Hoepner HT (2017) Sources of stakeholder salience in the responsible investment movement: why do investors sign the principles for responsible investment? J Bus Ethics 140:723-741. https://doi.org/10.1007/s10551-016-3057-2

Margolis JD, Elfenbein HA, Walsh JP (2009) Does it pay to be good...and does it matter? A meta-analysis of the relationship between corporate social and financial performance. SSRN J. https://doi.org/ 10.2139/ssrn.1866371

McCahery JA, Sautner Z, Starks LT (2016) Behind the scenes: the corporate governance preferences of institutional investors. J Finance 71:2905-2932. https://doi.org/10.1111/jofi.12393

Meng Y, Wang X (2020) Do institutional investors have homogeneous influence on corporate social responsibility? Manag Financ 46:301-322

Neubaum DO, Zahra SA (2006) Institutional ownership and corporate social performance: the moderating effects of investment horizon, activism, and coordination. J Manag 32:108-131. https://doi.org/ $10.1177 / 0149206305277797$

Nofsinger JR, Sulaeman J, Varma A (2019) Institutional investors and corporate social responsibility. J Corp Finan 58:700-725. https://doi.org/10.1016/j.jcorpfin.2019.07.012

Oh CH, Park J-H, Ghauri PN (2013) Doing right, investing right: socially responsible investing and shareholder activism in the financial sector. Bus Horiz 56:703-714. https://doi.org/10.1016/j.bushor. 2013.07.006

Oh WY, Chang YK, Martynov A (2011) The effect of ownership structure on corporate social responsibility: empirical evidence from Korea. J Bus Ethics 104:283-297

Oikonomou I, Yin C, Zhao L (2020) Investment horizon and corporate social performance: the virtuous circle of long-term institutional ownership and responsible firm conduct. Eur J Financ 26:14-40. https://doi.org/10.1080/1351847X.2019.1660197 
Pagano M, Volpin PF (2005) Managers, workers, and corporate control. J Finance 60:841-868. https:// doi.org/10.1111/j.1540-6261.2005.00748.x

Palacios-González MM, Chamorro-Mera A (2018) Analysis of the predictive variables of the intention to invest in a socially responsible manner. J Clean Prod 196:469-477. https://doi.org/10.1016/j.jclepro. 2018.06.066

Pekovic S, Vogt S (2020) The fit between corporate social responsibility and corporate governance: the impact on a firm's financial performance. Rev Manag Sci. https://doi.org/10.1007/ s11846-020-00389-x

Rees B, Mackenzie C (2011) Corporate social responsibility and the open society. SSRN J. https://doi. org/10.2139/ssrn.1966030

Revelli C, Viviani J-L (2015) Financial performance of socially responsible investing (SRI): what have we learned? A meta-analysis. Bus Ethics A Eur Rev 24:158-185. https://doi.org/10.1111/beer.12076

Reverte C (2016) Corporate social responsibility disclosure and market valuation: evidence from Spanish listed firms. Rev Manag Sci 10:411-435. https://doi.org/10.1007/s11846-014-0151-7

Riedl A, Smeets P (2017) Why do investors hold socially responsible mutual funds? J Finance 72:25052550. https://doi.org/10.1111/jofi.12547

Ryan LV, Schneider M (2003) Institutional investor power and heterogeneity. Bus Soc 42:398-429. https://doi.org/10.1177/0007650303260450

Schaltegger S, Hörisch J, Freeman RE (2019) Business cases for sustainability: a stakeholder theory perspective. Organ Environ 32:191-212

Sharfman MP, Fernando CS (2008) Environmental risk management and the cost of capital. Strat Mgmt J 29:569-592. https://doi.org/10.1002/smj.678

Shleifer A, Vishny RW (1997) A survey of corporate governance. J Finance 52:737-783. https://doi.org/ 10.1111/j.1540-6261.1997.tb04820.x

Sikavica K, Perrault E, Rehbein K (2018) Who do they think they are? Identity as an antecedent of social activism by institutional shareholders. Bus Soc. https://doi.org/10.1177/0007650318762752

Utz S (2019) Corporate scandals and the reliability of ESG assessments: evidence from an international sample. Rev Manag Sci 13:483-511. https://doi.org/10.1007/s11846-017-0256-X

van Gils A, Dibrell C, Neubaum DO, Craig JB (2014) Social issues in the family enterprise. Fam Bus Rev 27:193-205. https://doi.org/10.1177/0894486514542398

Velte P (2020) Institutional ownership, environmental, social, and governance performance and disclosure-a review on empirical quantitative research. Probl Perspect Manag 18:282-305. https://doi. org/10.21511/ppm.18(3).2020.24

Velte P, Stawinoga M, Lueg R (2020) Carbon performance and disclosure: a systematic review of governance-related determinants and financial consequences. J Clean Prod. https://doi.org/10.1016/j.jclep ro.2020.120063

Waddock SA, Graves SB (1997) The corporate social performance-financial performance link. Strateg Manag J 18:303-319. https://doi.org/10.1002/(SICI)1097-0266(199704)18:4\%3c303:AIDSMJ869\%3e3.0.CO;2-G

Walls JL, Berrone P, Phan PH (2012) Corporate governance and environmental performance: is there really a link? Strat Mgmt J 33:885-913. https://doi.org/10.1002/smj.1952

Wegener M, Elayan FA, Felton S, Li J (2013) Factors influencing corporate environmental disclosures. Account Perspect 12:53-73. https://doi.org/10.1111/1911-3838.12007

Williams RJ (2003) Women on corporate boards of directors and their influence on corporate philanthropy. J Bus Ethics 42:1-10. https://doi.org/10.1023/A:1021626024014

Winschel J, Stawinoga M (2019) Determinants and effects of sustainable CEO compensation: a structured literature review of empirical evidence. Manag Rev Q 69(3):265-328

Xiang C, Chen F, Jones P, Xia S (2020) The effect of institutional investors' distraction on firms' corporate social responsibility engagement: evidence from China. Rev Manag Sci. https://doi.org/10. 1007/s11846-020-00387-z

Zolotoy L, O'Sullivan D, Chen Y (2019) Local religious norms, corporate social responsibility, and firm value. J Bank Finance 100:218-233. https://doi.org/10.1016/j.jbankfin.2019.01.015

Publisher's Note Springer Nature remains neutral with regard to jurisdictional claims in published maps and institutional affiliations. 